\title{
Topoliada Paola Rumiza jako inspiracja do wielopoziomowego poznawania kultury włoskiej
}

Justyna Groblińska*, Katarzyna Kowalik**

Niedawno opublikowane w Polsce dzieło cenionego włoskiego dziennikarza i pisarza Paola Rumiza łączy w sobie wątki stanowiące niewyczerpane źródło inspiracji. W swoim literackim reportażu Legenda żeglujacych gór autor w oryginalny sposób interpretuje mit włoskiej kultury². W opisie osobistego doświadczenia odwołuje się do antycznego toposu homo viator, który służy mu do odtworzenia zapomnianych wątków historii i przedstawienia wynikającej z nich skomplikowanej panoramy włoskiej współczesności. Szlak wędrówki daleki jest od wielowiekowej europejskiej tradycji Grand Tour, kulturowej podróży po kontynencie szlakiem śladów historii i dzieł sztuki, w której Półwysep Apeniński stanowił podstawowy cel ${ }^{2}$. Środek lokomocji przeznaczony do drugiego etapu podróży również jest nietypowym wyborem - to model fiata 500 zwany topolino ${ }^{3}$. Jako swoista captatio

* Uniwersytet Łódzki, Wydział Filologiczny, Instytut Romanistyki, Zakład Italianistyki, 90-236 Lódź, ul. Pomorska 171/173, e-mail: justyna.groblinska@uni.lodz.pl.

** Uniwersytet Lódzki, Wydział Filologiczny, Instytut Romanistyki, Zakład Italianistyki, 90-236 Łódź, ul. Pomorska 171/173, e-mail: katarzyna.kowalik@uni.lodz.pl.

1 P. Rumiz, Legenda żeglujacych gór, tłum. J. Malawska, Wołowiec 2016.

2 Zainicjowana w XVII w. w Wielkiej Brytanii tradycja kulturowej podróży po kontynencie w kolejnych dwóch wiekach rozprzestrzeniła się wśród warstw arystokratycznych wielu krajów europejskich. Liczne pozostałości archeologiczne oraz galerie sztuki we Włoszech zadecydowały o ich popularności jako celu tej swoistej oświeceniowej turystyki. Za: http://www.treccani.it/ enciclopedia/grand-tour [dostęp: 13.06.2018].

3 Samochód, którym przemieszczał się po Apeninach triesteńczyk, został wyprodukowany w 1953 r. Wybór starego, niewygodnego auta, jak się okazało w trakcie podróży, miał swoje uzasadnienie. Autor niejednokrotnie dzięki pojazdowi zjednywał sobie napotkanych po drodze 
benevolentiae à rebours do lektury i wyruszenia w tę niezwykłą przygodę czytelnicy mogą odebrać padające na kartach książki znamienne słowa: „Drogi przyjacielu, ta twoja podróż otworzy ci wrota do zapomnianego i zapoznanego świata. Odnajdziesz duszę nieszczęsnego kraju, kochanego przez wszystkich, tylko nie przez Włochów"4. Stereotypowo pojmowana współczesna Arkadia okazuje się skrywać drugie, mniej sielankowe, ale równie fascynujące oblicze.

Przyjęta w założeniach dzieła strategia, polegająca na sięganiu do głębszych warstw włoskiej rzeczywistości niż w eksploatowanych przez przemysł turystyczny sloganach bel paese $e^{5}$ i dolce far niente ${ }^{6}$, staje się jasna, jeśli przyjrzymy się wcześniejszemu dorobkowi autora Legendy żeglujacych gór. Urodzony w 1947 roku dziennikarz i pisarz Paolo Rumiz specjalizuje się $\mathrm{w}$ tematyce międzynarodowej. Był korespondentem wojennym w czasie konfliktu w byłej Jugosławii, a w 2001 roku relacjonował z Islamabadu i Kabulu atak wojsk amerykańskich na Afganistan?. Jest związany z wydawaną w jego rodzinnym Trieście regionalną gazetą „Il Piccolo”8 oraz jednym z największych włoskich dzienników „La Repubblica”. Większość jego książek została wydana we Włoszech nakładem prestiżowego wydawnictwa Feltrinelli. Do jego najważniejszych dzieł należą: La secessione leggera (2001), Ė Oriente (2003), L'Italia in seconda classe (2009), La cotogna di Istanbul (2010), Il bene ostinato (2011), A piedi (2012), Trans Europa Express (2012), Morimondo (2013), Appia (napisana wraz z Riccardo Carnovalinim, 2016) oraz opublikowana we Włoszech w 2007 roku La leggenda dei monti naviganti, która, jako pierwsza książka autora, została wydana także

ludzi, a także dzięki powolnej i męczącej jeździe mógł lepiej pojąć trud życia w górach. Nazwa topolino stanowi także część złożenia topoliada, które pojawia się w tytule niniejszego artykułu. To określenie pada w reportażu (P. Rumiz, Legenda..., s. 567) i nawiązuje do nazwy środka transportu oraz Iliady Homera. Można się w nim dopatrywać także wyrazu toponim, który - jak zostanie to wykazane poniżej - odgrywa dużą rolę w Rumizowskiej wędrówce.

4 Ibidem, s. 370.

5 Wł. bel paese - piękny kraj, nazwa nadana przez antonomazję Włochom, o tradycji sięgającej XIV w. Po raz pierwszy określenie to zostało użyte w twórczości Dantego oraz Petrarki, http:// www.treccani.it/vocabolario/bel-paese [dostęp: 2.03.2018].

6 Wł. dolce far niente - słodkie nicnierobienie, włoskie wyrażenie oznaczające stan beztroskiego lenistwa, http://www.treccani.it/vocabolario/dolce1 [dostęp: 2.03.2018].

7 https://czarne.com.pl/katalog/autorzy/paolo-rumiz [dostęp: 2.03.2018].

8 http://ilpiccolo.gelocal.it/trieste [dostęp: 2.03.2018].

9 http://www.repubblica.it [dostęp: 2.03.2018]. 
w naszym kraju w 2016 r. w przekładzie Joanny Malawskiej jako Legenda żeglujacych gór ${ }^{10}$. Twórczość Rumiza zyskała duże uznanie w oczach krytyków i czytelników, czego potwierdzeniem są przyznane mu liczne nagrody literackie $^{11}$. Do Polski omawiany w niniejszym artykule tytuł wprowadziło Wydawnictwo Czarne, specjalizujące się między innymi właśnie w promowaniu współczesnych reportaży oraz literatury podróżniczej. Warto podkreślić, że jest ono współprowadzone przez znanego pisarza Andrzeja Stasiuka, który w swojej twórczości również porusza tematykę wypraw do obszarów odległych od wielkich metropolii ${ }^{12}$. Książka Rumiza ukazała się w serii Sulina, której celem jest „odkrywanie przed czytelnikiem nieznanych stron fenomenu zwanego Europa"13.

Nieznane oblicza jednego z najliczniej odwiedzanych państw na świecie Rumiz ukazuje nam dzięki oryginalnemu pomysłowi na swoją wyprawę. Pisarz w 2003 oraz 2006 roku odbył po Włoszech podróże szlakiem dwóch wielkich górskich pasm, Alp i Apeninów, od granicy ze Słowenia po Niceę oraz od Ligurii po Kalabrię. Wybór takiego szlaku, który miałby reprezentować całe Włochy, oraz dość paradoksalny tytuł książki uzasadnił: „Zza metafory gór, wyłaniających się z morza i żeglujących niczym Wielka Armada, ukazał mi się w pewnym momencie obraz Włoch otoczonych legenda" ${ }^{14}$. Dlaczego właśnie legendą? Być może dlatego, że cała relacja, niczym dawne opowieści, opiera się na ustnych relacjach spotykanych po drodze ludzi, którzy w rozmowie z przyjacielem snują historię swoich małych ojczyzn.

Paolo Rumiz przemierzył w ten sposób osiem tysięcy kilometrów - „tyle, ile wynosi odległość od wybrzeży Atlantyku do Chin” ${ }^{15}$. Ambitna górska wyprawa przybiera niemal skalę romantycznej podróży inicjacyjnej, w której odkrywamy utajoną duszę współczesnych Włoch i ich mieszkańców. Droga prowadziła bowiem z dala od popularnych

10 P. Rumiz, Legenda...

11 http://www.feltrinellieditore.it/opera/opera/la-leggenda-dei-monti-naviganti/\#premi [dostęp: 2.03.2018].

12 Por. A. Stasiuk, Opowieści galicyjskie, Wołowiec 2006; idem, Nie ma ekspresów przy zółtych drogach, Wołowiec 2013 (w szczególności rozdział 816, s. 39-41); idem, Kucajac, Wołowiec 2015; idem, Dukla, Wołowiec 1997.

13 Tekst z okładki, P. Rumiz, Legenda...

14 Ibidem, s. 13.

15 Ibidem, s. 9 . 
turystycznie miejsc. Nie ma na niej dużych miast ani atrakcji opisywanych w przewodnikach. Wręcz przeciwnie, autor wkraczał w większości do miejscowości, których nazwy odnaleźć można tylko na najdokładniejszych mapach:

Kto powiedział, że we Włoszech nie ma już terra incognita? Spróbujcie wjechać w Val Quaderna, kilka kilometrów od Bolonii. Zgubicie się. Poczujecie niepokojąca pustkę irańskiego pejzażu. Czy kiedykolwiek słyszeliście o Val Sillaro czy Valle Sallustra, które znajdują się tuż obok? Nawet nie próbujcie mówić, że tak, bo wam nie uwierzę. Apeniny są opustoszałe i nieznane. Odkrywasz je, tylko gdy korek wygoni cię z autostrady. Tylko w takim przypadku zdarza ci się odnaleźć nieskończony i fascynujący labirynt ${ }^{16}$.

Jego celem jest poznanie ludzi, którzy wbrew globalizacji i zdrowemu rozsądkowi pozostają wierni swoim małym, zapomnianym osadom. Nie bez powodu w opowieści pojawia się skojarzenie $z$ ostatnimi postaciami z historii Włoch, które związane były z górami - członkami ruchu oporu z czasów II wojny światowej ${ }^{17}$. Współcześnie ich rolę przejęli wytrwali mieszkańcy tych terenów, którzy dziś bardziej niż kiedykolwiek zmuszeni są do walki z arogancką władzą centralną o przetrwanie i zachowanie ekologicznej równowagi swoich małych ojczyzn.

Ruch oporu wciąż walczy, sześćdziesiąt lat po wojnie, i to z bardziej podstępnymi wrogami: obojętnościa polityki, zazdrością ludzką, głupim włoskim wstydem za wieśniaczą przeszłość i z wielkimi sieciami handlowymi, które wykańczają różnorodnośćc ${ }^{18}$.

Dzieło składa się z dwóch części odpowiadających utrwalonemu we włoskiej historii i kulturze podziałowi. Pierwsze pasmo górskie symbolizuje bogatą, dobrze rozwinięta, ,,europejską” północ kraju, a drugie - uboższe i mniej doceniane południe. Jak wielu Włochów, Rumiz ubolewa nad nierównymi szansami na rozwój kraju oraz wzajemnymi oskarżeniami jednej i drugiej strony. W pierwszej części książki przekazuje mieszkańcom północy głos na temat działalności Ligi Północnej - populistycznej partii politycznej, która postuluje oderwanie się regionów północnych od

16 Ibidem, s. 309.

17 Ibidem, s. 10.

18 Ibidem, s. 364.

Justyna Groblińska, Katarzyna Kowalik Topoliada Paola Rumiza jako inspiracja... 
reszty Włoch i utworzenie niezależnego państwa ${ }^{19}$, ale formułuje także swoje j'accuse wobec mediów, które nie pozwalają na zatarcie się mentalnych różnic w świadomości ludzi:

To oburzające, jak mało mówi się o Apeninach. W nagłówkach gazet pojawiają się pięć razy rzadziej niż Alpy. O słynniejszym łańcuchu mówi się stale, organizuje się konferencje [...]. A jednak Alpy to tylko zewnętrzna rama kraju. Apeniny tymczasem są jego duszą, żołądkiem, kręgosłupem. I są prawie dwukrotnie dłuższe. [...] Dlaczego te niesamowite terytoria o długiej i bogatej historii zajmuja podrzędne miejsce w zbiorowej wyobraźni narodowej? [...] Może jest coś nierozwiązanego w tożsamości Włoch ${ }^{20}$.

W przypadku miejscowości północnych Rumiz także zwraca uwagę na ignorowanie spraw ludzi zamieszkujących góry. Ich głos słyszalny jest najlepiej wtedy, kiedy zawiedzeni polityką władz centralnych przyłączają się do ruchów separatystycznych albo gdy na tamtych terenach wydarzy się jakaś tragedia. Emblematycznym przypadkiem jest ciążąca na współczesnych dziejach Włoch katastrofa zapory wodnej na rzece Vajont ${ }^{21}$, o której pisarz rozmawia ze znanym alpinistą i artystą Maurem Coroną. Niezatarte piętno tragedii, która pochłonęła niemal 2000 ofiar, oddają pełne melancholii słowa: „Cisza. Niepokojąca cisza. Nie słychać już nawoływań, kroków na bruku, brzęku sztućców dolatującego z okien, trzaskania ognia w kominkach, odgłosów heblowania. Zostały tylko kroki w pustce, tykanie czasu, które zmierza do zimy"22. Autor sugeruje jednak z pewnym zarzutem, że nawet bez tragedii proces wyludniania się tych rejonów prawdopodobnie musiałby nastapić:

19 Ibidem, s. 58.

20 Ibidem, s. 312-314.

21 Katastrofa w Dolomitach w regionie Friuli-Wenecja Julijska zdarzyła się w 1963 roku. Do poważnych zaniedbań doszło już na etapie budowy tamy, kiedy zauważono niestabilność gruntu i pierwsze przypadki osunięcia się terenu do zbiornika wodnego. Wbrew ostrzeżeniom specjalistów projekt zakładał stworzenie najwyższej w tamtym okresie zapory wodnej na świecie. Dnia 9 października 1963 roku osuwające się skały wywołały dwie potężne fale, które zalały okoliczne miejscowości. W późniejszym dochodzeniu stwierdzono fałszerstwa w dokumentacji, do których dopuściła się odpowiedzialna za budowę spółka SADE. Winni zostali skazani za nieumyślne spowodowanie katastrofy, ale przez kolejne dziesięciolecia trwały procesy o odszkodowania dla ofiar tragedii. Ostatecznie sprawa zakończyła się ugodą dopiero w 2000 r., http:// www.treccani.it/enciclopedia/vajont_\%28Dizionario-di-Storia\%29 [dostęp: 2.03.2018].

22 P. Rumiz, Legenda..., s. 72. 
W głębi duszy czai się ponura pewność, że to nie obryw Vajont spowodował zniszczenie tego świata, ale coś innego. Katastrofa jako alibi, ucieczka od zbiorowej odpowiedzialności za porzucenie, trochę jak po trzęsieniu ziemi w regionie Friuli, który wyparł się siebie w czasie odbudowy $^{23}$.

Podstawowym problemem tych niewielkich społeczności w obydwu pasmach górskich jest bowiem współcześnie ucieczka ludności i starzenie się społeczeństwa:

Kiedy widzisz piękny hotel w Apeninach, zanim poprosisz o pokój, upewnij się, czy nie jest to dom spokojnej starości. Łatwo się pomylić, bo są wszędzie i wyglądaja jak hotele [...] Apeniny to szpital dla przewlekle chorych i bez troskliwych kobiet z Europy Wschodniej zamieniłyby się w cmentarz ${ }^{24}$.

Oprócz niezrozumienia polityków właśnie to zjawisko wywołuje największą gorycz tych, którzy pozostali i wciąż usiłują walczyć o przyszłość swoich ziem. Bezpośrednio dotykające ich przemiany prowokują bohaterów książki Rumiza do gorzkich refleksji, a w konsekwencji także antropologicznych wręcz obserwacji na temat rzeczywistości zmieniającej się w sposób nieprzystający do warunków wspólnot tak odrębnych kulturowo, jak ich osady:

Wszystko zaczęło się od rozpadu patriarchalnej rodziny. To była idealna jednostka ekonomiczna, działająca bez marnotrawstwa, z poszanowaniem natury, generująca niskie koszty energetyczne. Jeden traktor wystarczał na trzydzieści, czterdzieści osób. Zniszczyliśmy ten system, żeby zachęcić do konsumpcji, ale niczym go nie zastąpiliśmy. Pojedyncze rodziny wypruwały sobie żyły, bo każda chciała mieć swoje poletko i swój traktor. I nie dali rady. I wyprzedali ziemię $e^{25}$.

Próba nadążenia za nowoczesnością na poziomie lokalnym doprowadziła jednak według rozmówców Rumiza do tego, że państwo o podziwianych przez inne narody bogatych tradycjach zaczęło stopniowo zatracać własną tożsamość. Doświadczenia pasterzy ze znajdującego się zawsze na

23 Ibidem.

24 Ibidem, s. 370-371.

25 Ibidem, s. 99.

Justyna Groblińska, Katarzyna Kowalik Topoliada Paola Rumiza jako inspiracja... 
marginesie historycznych wydarzeń Molise ${ }^{26}$ prowokują do postawienia sobie pytania na temat całościowo pojętej wizji kraju. Na przykład w opowieści o próbach wprowadzenia zakazu transhumancji ${ }^{27}$ mieszkaniec tego południowego regionu formułuje negatywną ocenę wobec działań państwa i ludzkich postaw: „zdegenerowane państwo”28 doprowadziło do ponownego zniewolenia swoich mieszkańców, bo „Włochy zaczęły się wstydzić swoich korzeni"29. Legenda żeglujacych gór obfituje w tego typu gorzkie stwierdzenia. Oczywiście, nie one same są tym, co wyróżnia dzieło na tle współczesnej literatury czy publicystyki. Śledząc włoskie media, na co dzień możemy spotykać się z krytycznymi opiniami wobec państwa, które w ostatnich latach pogrążyło się w kryzysie gospodarczym i mierzy się z problemem politycznej niestabilności. Siła publikacji Rumiza jest natomiast fakt, że autor oddaje głos zwykłym ludziom, którzy do tej pory nie mieli szansy wyrazić swojej opinii, a jak można wywnioskować z przytoczonych fragmentów - wbrew pozorom mają do powiedzenia bardzo wiele.

Ten efekt Rumiz uzyskuje z pewnością w znacznej mierze dzięki konwencji literackiego reportażu, w której utrzymana jest opowieść. O ile podstawowym założeniem jego projektu jest obserwacja Włoch pod względem geograficznym, to głębszy sens tego przedsięwzięcia leży jednak w odkrywaniu wyjątkowych osób, które najprawdopodobniej nigdy nie stałyby się bohaterami książki. Pisarz zyskuje zaufanie mieszkańców odwiedzanych przez siebie wsi i miasteczek dzięki umiejętności zrozumienia odrębności ich kultury i stylu życia. Sławny dziennikarz i podróżnik spełnia funkcje reportera-słuchacza ${ }^{30}$. Zgodnie z prawidłami gatunku, także w analizowanej włoskiej publikacji

26 We Włoszech funkcjonuje wręcz humorystyczno-deprecjonujące stwierdzenie Il Molise non esiste - Molise nie istnieje. Na satyrycznych stronach internetowych można odnaleźć „dowody na nieistnienie Molise": nikt nie pamięta, jak nazywa się stolica regionu, nikt nie zna typowej dla niego potrawy ani piosenki, nie urodziła się tam nigdy żadna słynna postać (a nawet jeżeli się urodziła, to jest to postać równie fikcyjna, jak Molise), http://nonciclopedia.wikia.com/wiki/ Dimostrazione_dell\%27inesistenza_del_Molise [dostęp: 2.03.2018].

27 Transhumancja - rodzaj pasterstwa polegającego na przepędzaniu stad z pastwisk górskich w doliny w okresie zimowym.

28 P. Rumiz, Legenda..., s. 477.

29 Ibidem, s. 479.

30 Mariusz Dzięglewski podaje za Kazimierzem Wolnym cztery formy udziału reportera w opisywanym w tekście wydarzeniu: reporter jako świadek, reporter jako uczestnik przedstawionych zdarzeń, reporter jako słuchacz, reporter jako rekonstruktor zdarzeń. K. Wolny, O poetyce 
[p]ytania reportera podczas wywiadu nie zawsze są wcześniej przygotowane, często rodzą się w toku wywiadu, czasami są jedynie próbą sprowokowania rozmówcy do dłuższej wypowiedzi, która później stanowi materiał (surogat) do reportażu. [...] [R]eporter dostosowuje się do sytuacji, zmienia kolejność pytań i stawia nowe ${ }^{31}$.

W swojej metodzie pracy autor bierze przykład z Ryszarda Kapuścińskiego, co bezpośrednio przyznaje w Legendzie żeglujacych gór. Rady udzielone mu przed laty przez autora Imperium, w opinii Rumiza - „,największego reportera powojennego"32, ukształtowały jego dziennikarsko-literackie rzemiosło:

Kapuściński, jeden z niewielu dziennikarzy na świecie, jechał w miejsca nieoczywiste, gdzie nie było świateł reflektorów. Daleko, jak najdalej od medialnego show. [...] W czym tkwi jego siła? Jak on to robi, człowiek o wyglądzie wiejskiego proboszcza, że zawsze wraca z notesami pełnymi historii? W czasie lotu z Zurychu do Mediolanu zauważyłem, że dziękował za każdą najmniejszą rzecz.

- Nasz zawód zależy od innych - uśmiechał się, jakby przepraszając za swoją uprzejmość. - Jeśli nie szanujesz ludzi, drzwi zamykają się przed toba. $[\ldots]$

Schodzimy w kierunku gospodarstwa Seberg, żeby spotkać się z grupą trydenckich studentów [...]. Mistrz jest szczęśliwy, uwielbia przebywać z młodymi, z dala od kamer telewizyjnych. [...] Wszyscy są oczarowani prostotą jego pytań, jego dziecięcą ciekawością, brakiem cynizmu i ciągłym zdziwieniem. [...] - Ja jestem na służbie publicznej, jeśli chodzi o informację. - Pyta młodych o nich samych, atakuje pytaniami, zachęca do przebywania z biednymi. - Nie możecie ich ignorować, jeśli chcecie uprawiać ten zawód. Biedacy stanowią osiemdziesiąt procent ludności globu [...]. - Musicie jeść z ludźmi, o których piszecie. Cierpieć z nimi głód. Maksymalnie się do nich upodobnić. [...] Jest pustka, wy, młodzi, też ją czujecie. Macie internet? To prawda. Ale wam to nie wystarcza, bo wiecie, że jesteście manipulowani. I dlatego zaczynacie szukać starych narzędzi [...]. Potrzebujecie naocznego świadka czasu ${ }^{33}$.

wspótczৃesnego reportażu polskiego 1945-1985, Rzeszów 1991, s. 94-129, za: M. Dzięglewski, Reportaże

Rysz̧arda Kapuścinskiego. Źródto poznania spoteczeństw i kultur, Lublin 2009, s. 89.

31 Ibidem, s. 90.

32 P. Rumiz, Legenda..., s. 135.

33 Ibidem, s. 137-139.

Justyna Groblińska, Katarzyna Kowalik · Topoliada Paola Rumiza jako inspiracja... 
W warsztacie pisarskim Paola Rumiza zdecydowanie widać wpływ polskiego reportażysty. Opisom poszczególnych miejscowości, spotkań i odkryć towarzyszy rzecz jasna odautorski, subiektywny komentarz. Pod tym względem autor nawiązuje do korzeni reportażu, na którego ukształtowanie się znaczący wpływ miało pamiętnikarstwo ${ }^{34}-$ gdyż także swego rodzaju dziennikiem podróży możemy nazwać Legende żeglujacych gór. Przeważaja w niej jednak nie refleksje autora, a ludzkie wspomnienia, na podstawie których rysuje się obraz współczesnych Włoch, dopełniony aspektami nieobecnymi w skoncentrowanych na wielkich wydarzeniach środkach przekazu. I mimo że „[w]izje przyszłości i przeszłości w świadomości jednostek trudne są do uchwycenia nie tylko dla reportera, ale nawet dla badacza - socjologa i antropologa kultury. [...] Sposób, w jaki ludzie reagują na drugiego człowieka czy na wydarzenia zachodzace w ich najbliższym otoczeniu, emocje, jakie się w nich wyzwalają, są bardzo trudne do uchwycenia i opisania" 35 , to Rumiz decyduje się na to ryzyko, przedstawiając nam być może na poziomie jednostkowego bohatera subiektywny, ale w ramach całego cyklu rozmów zdecydowanie pluralistyczny i wartościowy obraz współczesnych Włoch.

Autor Legendy wpisuje się ponadto w znamienny dla Ryszarda Kapuścińskiego proces przeprowadzania reportażu na stronę literatury ${ }^{36}$ i przejmuje od niego wzorzec zaangażowania w opisywaną tematykę. Autor deklaruje, że jego praca wynika z poczucia misji wobec ludzi, którym poświęca swoje dzieło: „Jestem przekonany, [...] że dziennikarze powinni opowiadać o tych milczących ziemiach i być ich głosem" "37. Na kartach Legendy szeroko komentowane są zatem błędy kolejnych rządów, które w przyszłości mogą wywołać katastrofalne konsekwencje:

Jeśli politycy nie opuszczą swych helikopterów i nie nauczą się chodzić, to Włochy rychło staną się ziemią szarańczy i będziemy mieć tysiące przedmieść kipiących furią bezsilności. Ciemiężone i lekceważone peryferie

34 J. Maziarski, [hasło] Reportaz, [w:] Stownik rodzajów i gatunków literackich, red. G. Gazda, Kraków 2006, s. 935.

35 M. Dzięglewski, Reportaże..., s. 173.

36 Z. Ziątek, Śladami mistrz̧a. Znaczenie Kapuścińskiego w nowej sytuacji polskiego reportażu, [w:] Metamorfozy podróźy. Kultura i tożsamość, red. J. Sztachelska, Białystok 2012, s. 425-435.

37 P. Rumiz, Legenda..., s. 13. 
mszczą się, a góry są takimi właśnie peryferiami. Liga Północna, która zeszła z górskich dolin, była tylko pierwszym sygnałem zła. Nie należy lekceważyć fanatyzmu - a on rodzi się z zapomnienia i odrzucenia ${ }^{38}$.

Dzieło Rumiza nie jest jednak z pewnością wyłącznie zbiorem pesymistycznych rozważań. Pisarz staje się głosem górskiej ludności także w aspekcie promowania ich tradycji oraz pięknych terenów omijanych przez turystów. Włoskie góry to wieloetniczny obszar, gdzie mieszają się kulturowe wpływy, a w każdej miejscowości odnaleźć można wyjątkowe zwyczaje. Paolo Rumiz przywraca pamięć o dawnych bohaterach i pokazuje niezwykłych ludzi: rolników, pasterzy, migrantów, których silne charaktery zostały ukształtowane przez trudne warunki życia.

Warto zauważyć, że autor Legendy nie poświęca uwagi jedynie napotkanym osobom. Cechuje go duża wrażliwość językowa. „Wystarczy zaufać nazwom" 39 - to znamienne słowa włoskiego reportażysty nie tylko ze względu na kontekst i przywrócenie wartości mapie, lecz także na onomastyczne oraz etymologiczne zainteresowania. Nazwa dla przeciętnego turysty jest transparentna i pełni przede wszystkim funkcję znaku informacyjnego, natomiast dla Rumiza, niczym dla językoznawcy, kryje w sobie głębszy sens. W swojej literackiej podróży triesteńczyk często koncentruje się na toponimach i nadaje im duże znaczenie. Niejednokrotnie reporterska wędrówka zamienia się w metajęzykową wyprawę. Toponomastyczna ${ }^{40}$ wrażliwość autora odkrywa przed czytelnikiem nie tylko mało dostępne miejsca na mapie Włoch, ale i historie ich nazw. Jako przykład można wskazać górę nazywaną przez pewien czas Monte Sòmega - Góra Nie Wiem. Miejscowa ludność nie znała jej nazwy i sformułowanie nie wiem wpisano do rejestru, co niechybnie przekształciło się w onim ${ }^{41}$. Ta nietypowa etymologia prowadzi do innej obserwacji Rumiza: ,[...] póki trwają nazwy, tak długo będą istnieć miejsca" "42. Przyjmując ten tok rozumowania, nie sposób zatem nie podważyć istnienia Góry Nie Wiem. Autor nie tyle neguje fizyczne istnienie nienazwanego miejsca, ile sugeruje, że

38 Ibidem, s. 12-13.

39 Ibidem, s. 308.

$40 \mathrm{~W}$ wielu fragmentach książki pojawiają się omówienia oronimów (stanowiących podkategorię toponimów) - nazw wzniesień, gór, masywów górskich.

41 P. Rumiz, Legenda..., s. 541.

42 Ibidem, s. 125. Przeświadczenie autora o sile nazewnictwa uwidacznia się wielokrotnie: „[...] nazwa jest wszystkim - jeśli ją utracisz, stajesz się nikim [...]” (ibidem, s. 502-503). 
brak nazwy prowadzi do zaniku pamięci o jego historii. W ten sposób podkreśla istotę toponimii i jej znaczenie dla kształtowania społecznej świadomości kulturowej. W książce wielokrotnie padaja przykłady nazw tworzących tożsamość danego obszaru i wpływających na nastrój zarówno mieszkańców, jak i podróżników ${ }^{43}$.

Także w powietrzu unosiło się coś tajemniczego. Zrozumiałem to w Górach Sybillińskich. Poznałem to po sybillińskim spojrzeniu barmanki hotelu Sybilla, po jej fenickich oczach - szarych ze złotymi pręcikami - gdy z głębi półcienia zamieszkanego przez dziewczęce śmiechy i pachnącego soczewicą z ragù powiedziała: „Proszę uważać, wjeżdża pan na tajemne ziemie”. I nawet jeśli na zewnątrz, nad polaną Castelluccio, ciche paralotnie unosiły się nad łąkami lśniącymi od świeżego śniegu, wszędzie wokoło takie miejsca jak Monte Utero (Góra Macicy), Màcera di Morte (Ostępy Śmierci) czy wąwóz Infernaccio (Piekielnik) świadczyły o nekromancji. Same ich nazwy wystarczały, żeby odczuć, że dotykam krawędzi otchłani ${ }^{44}$.

Rumiz zwraca uwagę, że współcześnie nie wszystkie nazwy kreują atmosferę. Według niego starsze toponimy znaczą więcej i mają duszę, podczas gdy nowsze postrzegane są przez niego jako bezdźwięczne i zgaszone. Timpa del Demonio (Diabli Bębenek ${ }^{45}$ ) czy Passo della Femmina Morta (Przełęcz Umarłej Kobiety) rzeczywiście pobudzają wyobraźnię czytelnika czy osoby zwiedzającej, natomiast Brescia - Zachód sprawia wrażenie suchej, urzędniczej informacji ${ }^{46}$.

Językowe zainteresowania Rumiza tworzą nową koncepcję toponomastycznej podróży wytyczanej niekiedy bardziej przez nazwy miejsc aniżeli przez szlaki i drogi. Czytelnik-podróżnik ma pochylić się nad etymologia nazw i zwiedzać Włochy, wnikając głęboko w onomastyczną warstwę tej kultury. Ma poznawać nową rzeczywistość poprzez logos i zrozumieć, że w nazwach znajdzie odpowiedzi na wiele pytań i odkryje wiele tajemnic. Dowie się chociażby, że Apeniny to kraina zwierząt ${ }^{47}$ (które jednak powoli znikają z włoskiego krajobrazu) - Passo dell’Agnello (Przełęcz Baranka), Vaccarizza

$43 \mathrm{O}$ tym, że nazwy własne mówią i mają znaczenia, por. np. E. Rzetelska-Feleszko, $W$ świecie naz̨w własnych, Warszawa-Kraków 2006, s. 185-188.

44 P. Rumiz, Legenda..., s. 446. W nawiasach podane są polskie odpowiedniki nazw zaproponowane przez Joannę Malawską - tłumaczkę książki.

45 Ibidem.

46 Ibidem, s. 308-309.

47 Ibidem, s. 356. 
(Stojąca Krowa) czy Strangolagalli (Dusiciel Kogutów). To o tyle istotne, że według Rumiza zjawisko obcowania z natura i poszanowania jej przemija.

Zaniedbany ekosystem, przewaga globalizacji nad regionalizacja, wyludnianie i pustynnienie górskich obszarów we Włoszech to wątki powiązane z odchodzeniem w niepamięć świata zwierząt. Uwaga poświęcona tym zagadnieniom sytuuje Legende żeglujacych gór wśród publikacji literackich wpisujących się w założenia ekokrytyki ${ }^{48}$, którą „,[...] interesuje przede wszystkim to, w jaki sposób pozbawiono przyrodę głosu" "49. Rumiz, przemierzając górskie szlaki i słuchając swoich rozmówców, znajduje wiele przyczyn, dla których praktycznie niesłyszalny jest głos natury. Wysychanie wód czy osunięcie się góry to jedynie skutki takich zjawisk, jak rozwój przemysłu, poszukiwanie nowych źródeł energii elektrycznej, globalizacja ${ }^{50}$.

Jak zostało wspomniane na początku, większość Rumizowskich uwag komentujących zastaną przezeń włoską rzeczywistość przywołuje na myśl twórczość Andrzeja Stasiuka, a w szczególności zbiór tekstów Kucajac ${ }^{51}$. Pisarzy łączą powrót na łono natury, odwrót od antropocentryzmu (choć w przypadku włoskiego autora - bardziej subtelny, gdyż on zdaje się koncentrować na obydwu światach, ludzkim i zwierzęcym, podczas gdy uwagę polskiego reportażysty bardziej zdają się zajmować zwierzęta), a także milczące nostalgia i tęsknota za zjawiskiem nie do końca określonym, które jednak prawdopodobnie jest minionym, uważniejszym i powolniejszym światem. Jednocześnie obydwaj zdają się krzyczeć do czytelników i budzić ich ze snu ekologicznej ignorancji.

Triesteńczyk, decydując się na dwie wyprawy - w Alpy i Apeniny, dzieli się swoim punktem widzenia, odciagając uwagę czytelnika od krajobrazów, które jako pierwsze nam, obcokrajowcom, przychodzą na myśl. Nie przedstawia po raz kolejny pięknych plaż w blasku gorącego południowego słońca, a obnaża góry, które - choć dominują na półwyspie ${ }^{52}$

48 Jest to niewątpliwie dzieło demaskujące włoską rzeczywistość i odkrywające realistyczny obraz gór - o tych elementach wspomina Anna Barcz, opisując ekokrytykę w literaturze, por. A. Barcz, Realizm ekologiczny. Od ekokrytyki do zookrytyki w literaturze polskiej, Katowice 2016, s. 10, 22-24.

49 Ibidem, s. 38.

50 Ibidem, s. 41.

51 Potwierdza to A. Barcz - ibidem, s. 83-84. Por. także A. Stasiuk, Kucajac, s. 5-128.

52 Według Istat (Istituto nazionale di statistica - krajowy urząd statystyczny, odpowiednik polskiego GUS) 35,2\% ukształtowania terenu stanowią we Włoszech góry, a 41,6\% - wzgórza. Pozostałe $23,2 \%$ to obszary nizinne, por. https://www.istat.it/it/archivio/137001 [dostęp: 2.03.2018]. 
- często pomijane są w naszych wyobrażeniach lub stanowią jedynie tło malowniczych wybrzeży czy też grzęzną w świadomości turystów jako pofałdowanie terenu. Dzięki Rumizowi czytelnik ma niepowtarzalna okazję ujrzeć góralskie oblicze Włoch. Oblicze, które powoli staje się przeszłością, gdyż - jak dowodzi autor - ten świat zanika. Jak zostało to zasygnalizowane, przyczyn zmian zachodzących we włoskich górach jest wiele, ale dwa najważniejsze i ściśle związane ze sobą czynniki to rozwój technologii i przemysłu oraz globalizacja. W czasie ostatnich kilkudziesięciu lat Włosi licznie opuszczali góry ze względu na umniejszenie roli pasterstwa, pustynnienie terenów, na których sztucznie zaczęto regulować gospodarkę wodną, uprzemysłowienie miast, a także atrakcyjniejsze zarobki w fabrykach, wzrost konsumpcjonizmu i wpływów globalizacji (m.in. migracja z południa Włoch na północ oraz z całego kraju za granicę $)^{53}$. Nie dziwi zatem fakt, że w wyobrażeniach przeciętnego Europejczyka Włosi nie są góralami, a raczej przedsiębiorcami produkującymi samochody czy projektantami mody i mistrzami designu. Związek mieszkańców Półwyspu Apenińskiego z ich ziemią zanika, co również stoi w opozycji do stereotypowego włoskiego campanilismo ${ }^{54}$, i nawet takie zabiegi, jak ochrona lokalnego wytwórstwa ${ }^{55}$, często nie zatrzymują młodych w kraju, nie wspominając o pozostaniu na terenach trudniej dostępnych. Jeden z rozmówców Rumiza podkreśla to, co już zostało zasygnalizowane: współczesne pasterstwo jest niczym ruch oporu - zajmuja się nim nieliczni, starają się pokonać przeszkody stawiane przez rząd i wielkie sieci handlowe, a swoje zajęcie traktują jak pasję i sztukę ${ }^{56}$.

53 P. Rumiz, Legenda..., s. 71-81, 96-103, 121-125, 176-183, 257-265, 392-411, 456, 475-484, 554-561. To wybrane fragmenty książki, w których ekokrytyka jest głównym tematem, jednak należy podkreślić, że całe dzieło ma taki wydźwięk.

54 Wł. campanilismo - regionalny patriotyzm.

55 Zauważalna przede wszystkim w enogastronomii - na etykietach włoskich produktów spożywczych i win często widnieją atesty (D.O.C. - Denominazione di Origine Controllata, DOP - Denominazione di Origine Protetta, D.O.C.G. - Denominazione di Origine Controllata e Garantita czy IGP - Indicazione Geografica Protetta) gwarantujące jakość produktów i dbałość o obecność na rynku włoskich producentów. Podobnym zabiegiem gospodarczym jest próba przywracania wyrobów rzemieślniczych (wł. prodotti artigianali), których wytwarzanie ma uchronić od zaniku ginące zawody oraz wysokiej jakości produkty, z którymi nie mogą się równać ich odpowiedniki pochodzące z masowej produkcji.

56 P. Rumiz, Legenda..., s. 475-484. 
Polski czytelnik w trakcie podróży Rumiza nie tylko pozna nowe oblicze włoskich realiów, lecz także co najmniej kilkakrotnie zwróci się w stronę swojej ojczyzny. Najważniejszym polskim wątkiem jest omawiane już wspomnienie o Ryszardzie Kapuścińskim. To hołd ucznia oddawany mistrzowi, który dodatkowo obejmuje wspomnienie o ważnym dla obydwu antropologu i prekursorze reportażu, Bronisławie Malinowskim $^{57}$, a dokładnie o wizycie w Bolzano, gdzie ten ostatni mieszkał przez kilkanaście lat. Kapuściński poczynił na ten temat istotną uwagę, mówiąc Rumizowi, że w trakcie pobytu we Włoszech Malinowski nic nie napisał, a przyczyną tej przerwy miało być rozpraszające otaczające go piękno.

Podróżnicy nie są jedynymi Polakami, którym poświęca uwagę włoski pisarz. Obecność Polek i innych Słowianek także zostaje zauważona. Rumiz przywołuje zaskakujące powiedzenie krążące po południowej części półwyspu Me giglio 'na polacca ${ }^{58}$. Tłumaczy je złożone zjawisko sięgające czasów powstania fabryki Fiata (lata pięćdziesiąte XX wieku), kiedy doszło do wspomnianej już migracji mieszkańców północnych wsi do miast, w szczególności do Turynu, gdzie szybko rozwinął się przemysł samochodowy. Za nimi wyruszyły do miast kobiety, a mężczyźni, którzy zdecydowali się pozostać w swoich małych ojczyznach, zaczęli szukać żon wśród kobiet pochodzących z południa kraju. Jednak i Włoszki z tej części półwyspu po pewnym czasie przestały przeprowadzać się do północnych wsi i zaczęły przenosić się do miast. Migracje te miały spowodować wzmożone poszukiwanie żon wśród obywatelek Europy Wschodniej, w tym także wśród Polek.

Poza obecnością naszych rodaków we Włoszech Rumiz wspomina o historyczno-kulturowych nietaktach, jakie wkradają się niekiedy do branży turystycznej. W Predappio, rodzinnej miejscowości Benita Mussoliniego, ogląda stoisko z faszystowskimi gadżetami dla turystów. Kontrowersyjny widok przypomina mu polską ofertę wycieczki obejmującej jednorazowo: zwiedzanie byłego obozu koncentracyjnego Auschwitz-Birkenau w Oświęcimiu, zakupy w kramach z bursztynem oraz oglądanie występu prezentującego muzykę ludową.

57 Ibidem, s. 134-142.

58 Wł. Me giglio 'na polacca - wezmę sobie jakąś Polkę. P. Rumiz, Legenda..., s. 515-517. 
Polskie wątki tworzą niewielką część Rumizowskiej podróży, niemniej jednak są istotne dla czytelnika z kraju nad Wisłą. Zarówno warsztatowo, jak i światopoglądowo włoski reportażysta łączy się, bezpośrednio lub na poziomie wspólnej myśli, z polskimi przedstawicielami literackiej wędrówki (Malinowskim, Kapuścińskim, Stasiukiem), a uznanie włoskiego autora dla Ryszarda Kapuścińskiego potwierdza tylko istotę kontaktów polsko-włoskich i siłę wzajemnego oddziaływania tych dwóch kultur ${ }^{59}$.

Triesteński pisarz umożliwia zarówno Włochom odkrycie nowych pokładów ich kulturowej tożsamości, jak i obcokrajowcom zwiedzenie tego kraju w nietypowy sposób. Tym samym realizuje podstawowe cele reportażu literackiego według Ryszarda Kapuścińskiego, zaczerpnięte z klasyfikacji Dzięglewskiego:

- budowanie zrozumienia („mostów”) pomiędzy społeczeństwami,

- dostarczanie czytelnikom wiedzy o innych kulturach,

- dostarczenie wiedzy niezbędnej do ogólnego zrozumienia świata [...],

- inspirowanie do dalszego poszukiwania i pogłębiania wiedzy na temat innych kultur i problemów współczesnego świata ${ }^{60}$.

Rumiz, czerpiąc z dokonań mistrzów, pisze swój udany reportaż po Włoszech, jakich nie znamy. Zrywa z ich utopijną legenda, ale w zamian tworzy nową i nie mniej intrygującą opowieść. Wędruje śladami pamiętającej czasy wojny, starzejącej się demograficznie Italii, ostatkami sił usiłującej ocalić swoją kulturę i przyrodę. Na chwilę zatrzymuje czas i zmusza czytelnika do zatrzymania się w biegu codzienności. Choć nie zdradza wszystkich swoich odkryć, chroniąc je pod osłoną fikcji literackiej, zaprasza do uważnej i nostalgicznej wędrówki po góralskich Włoszech.

59 Syntezę tych kontaktów, z naciskiem na ich historię, zob. S. Widłak, Italia e Polonia. Popoli e lingue in contatto, Kraków 2006, s. 57-68.

60 M. Dzięglewski, Reportaże..., s. 204. 
Bibliografia

Barcz A., Realizm ekologiczny. Od ekokrytyki do zookrytyki w literaturze polskiej, Katowice 2016.

Dzięglewski M., Reportą̧e Ryszarda Kapuścinskiego. Źródto poznania spoteczeństw $i$ kultur, Lublin 2009.

Maziarski J., [hasło] Reportaż, [w:] Stownik rodzajów i gatunków literackich, red.

G. Gazda, Kraków 2006, s. 933-935.

Rumiz P., Legenda żeglujacych gór, tłum. J. Malawska, Wołowiec 2016.

Rzetelska-Feleszko E., W świecie nažw własnych, Warszawa-Kraków 2006.

Stasiuk A., Dukla, Wołowiec 1997.

Stasiuk A., Kucajac, Wołowiec 2015.

Stasiuk A., Nie ma ekspresów przy żóttych drogach, Wołowiec 2013.

Stasiuk A., Opowieści galicyjskie, Wołowiec 2006.

Widłak S., Italia e Polonia. Popoli e lingue in contatto, Kraków 2006.

Ziątek Z., Śladami mistræa. Znaczenie Kapuścińskiego w nowej sytuacji polskiego reportażu, [w:] Metamorfozy podróży. Kultura i tożsamość, red. J. Sztachelska, Białystok 2012, s. 425-435.

\section{Netografia}

http://ilpiccolo.gelocal.it/trieste [dostęp: 2.03.2018].

http://nonciclopedia.wikia.com/wiki/Dimostrazione_dell\%27inesistenza_

del_Molise [dostęp: 2.03.2018].

http://www.feltrinellieditore.it/opera/opera/la-leggenda-dei-monti-navi-

ganti/\#premi [dostęp: 2.03.2018].

http://www.repubblica.it [dostęp: 2.03.2018].

http://www.treccani.it/enciclopedia/grand-tour [dostęp: 13.06.2018].

http://www.treccani.it/enciclopedia/vajont_\%28Dizionario-di-Storia\%29

[dostęp: 2.03.2018].

http://www.treccani.it/vocabolario/bel-paese [dostęp: 2.03.2018].

http://www.treccani.it/vocabolario/dolce1 [dostęp: 2.03.2018].

https://czarne.com.pl/katalog/autorzy/paolo-rumiz [dostęp: 2.03.2018].

https://www.istat.it/it/archivio/137001 [dostęp: 2.03.2018]. 
Topoliada Paola Rumiza jako inspiracja do wielopoziomowego poznawania kultury wtoskiej

W artykule analizowane są inspiracje wypływające z lektury reportażu literackiego Legenda żeglujacych gór Paola Rumiza. Włoski pisarz i dziennikarz opisuje w nim swoje wielomiesięczne podróże po Półwyspie Apenińskim szlakiem jego dwóch największych pasm górskich - Alp i Apeninów. Celem wyprawy było dotarcie do miejsc zapomnianych przez turystykę i polityków. Rozmowy z napotkanymi w drodze mieszkańcami ukazują oblicze Italii nieznanej, innej od tej przedstawianej w wielu tekstach kultury czy w przewodnikach turystycznych. Z jednej strony niewielkie górskie miejscowości mierzą się z problemami demograficznymi i ekologicznymi, ale z drugiej - moga poszczycić się szczególnymi tradycjami, które warto poznać i kultywować. Swój dziennikarski warsztat autor opiera na doświadczeniach polskiego mistrza reportażu - Ryszarda Kapuścińskiego. Legenda غ̇eglujacych gór wykazuje ponadto wiele zbieżności z tematyką utworów Andrzeja Stasiuka. Paolo Rumiz w swojej książce inspiruje czytelników do nieszablonowego spojrzenia na Włochy.

\section{Topoliad of Paolo Rumiz as an inspiration to multi-level learning about Italian culture}

The article is dedicated to the inspirations coming from literary reportage Leggenda dei monti naviganti by Paolo Rumiz. The Italian writer and journalist describes his journeys across Italian Peninsula through two most important mountain ranges - the Alps and the Apennines. The objective of this expedition was to arrive to places forgotten by tourism and politicians. The conversations with citizens met on the way show the unknown aspects of Italy, different from its common image in culture texts or travel guides. Small mountain villages have to face the demographic and ecological problems. On the other side, they can be proud of particular traditions that should be known and preserved. The journalistic approach of the author is based on experiences of the Polish reportage master - Ryszard Kapuściński. The work presents also numerous analogies with topics of Andrzej Stasiuk's writing. Paolo Rumiz in his book inspires the readers to look at Italy in unconventional way. 